\title{
RADON IN THE FLUVIAL AQUIFERS OF THE WHITE RIVER BASIN, INDIANA, 1995
}

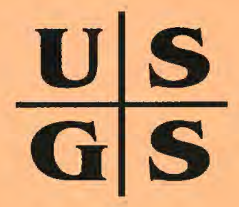

U.S. Department of the Interior-U.S. Geological Survey

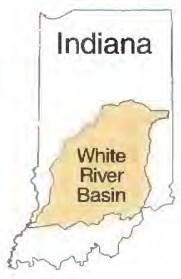

\begin{abstract}
Water samples collected in 1995 from 57 monitoring wells (48 shallow and 9 deep) in the fluvial aquifers of the White River Basin were analyzed for radon. Radon concentrations in the shallow wells ranged from 140 to $1,600 \mathrm{pCi} / \mathrm{L}$ (picocuries per liter); the median concentration was $420 \mathrm{pCi} / \mathrm{L}$. In comparison, analyses of the samples from the nine deep wells indicate that radon concentrations decrease with depth within the fluvial aquifers; the median concentration was $210 \mathrm{pCi} / \mathrm{L}$. No areal trends in radon concentrations are evident in the water of the shallow fluvial aquifers of the basin.
\end{abstract}

\section{INTRODUCTION}

Water samples collected in 1995 from 57 monitoring wells in the fluvial aquifers of the White River Basin were analyzed for dissolved radon as part of the National Water-Quality Assessment (NAWQA) Program (Hirsch and others, 1988). The White River Basin is part of the Mississippi River system and encompasses 11,350 square miles of central and southern Indiana (fig. 1).

The population of the White River Basin in 1990 was approximately 2.1 million people; the Indianapolis Metropolitan Area accounted for about 60 percent of the total population. Approximately 55 percent of the population in the White River Basin rely on ground water as the primary source of drinking water. In 1993, about 180 million gallons per day (Mgal/d) of ground water were withdrawn from the basin. Of total ground-water withdrawals in the basin, public-water suppliers accounted for about 51 percent (91 Mgal/d), followed by self-supplied domestic users ( 23 percent), and self-supplied industrial and commercial users (20 percent) (Indiana Department of Natural Resources, Division of Water, written commun., 1995).
The fluvial aquifers are the most productive aquifers in the White River Basin (Fenelon and others, 1994). The aquifers generally range in thickness from 10 to 100 feet and consist of glacial outwash and recent river deposits of sand, gravel, and silt that underlie most of the major rivers and streams in the basin. The most extensive fluvial aquifers are along the White River near Indianapolis and south of Bloomfield, and along the East Fork White River near Columbus and Seymour.

Radon-222 (referred to here as radon) is a human carcinogen (U.S. Environmental Protection Agency, 1995). It is a radioactive, odorless, chemically inert gas that occurs naturally in the sands and gravels of the fluvial aquifers. Radon is a daughter product of radium-226-a decay product of uranium-238. Radium-226 is present in sands and gravels derived primarily from granites of the Canadian Shield and from uraniumbearing shales of north-central Indiana. Radon has a half life of 3.8 days and, in ground water, is not transported far from its radium-226 source before it almost completely decays. Because of radon's chemical inertness and short half life, the principal factor affecting its distribution in ground water is the distribution of uranium-bearing minerals in the aquifer matrix.

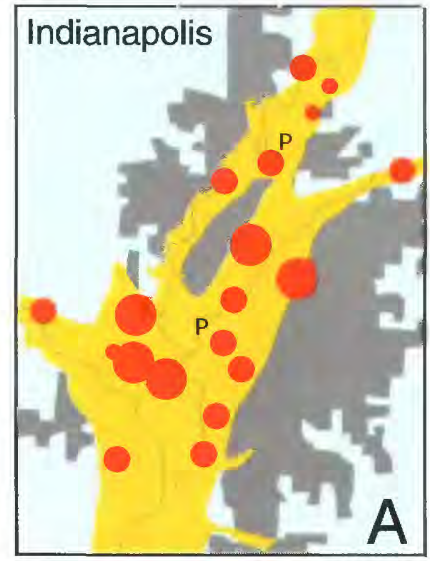

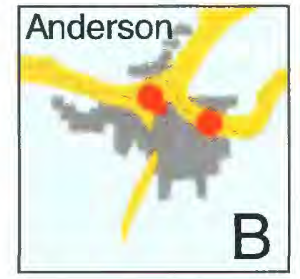

Urban areas on insets are shaded grey

\section{EXPLANATION}

FLUVIAL AQUIFER WELL LOCATION AND DISSOLVED
RADON CONCENTRATION, IN PICOCURIES PER LITER

- less than or equal to 300

310-600

greater than 600

P PAIRED WELL SITE
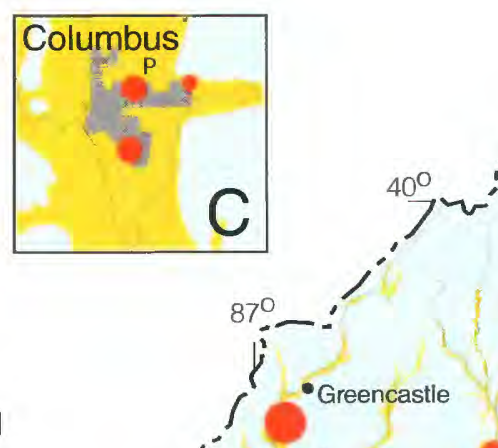

$86^{\circ}$

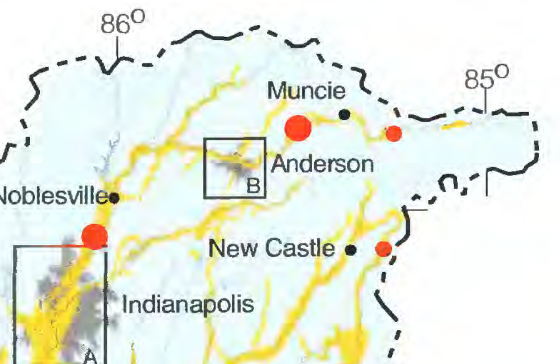

Figure 1. Distribution of radon concentrations in water from shallow monitoring wells in the fluvial aquifers of the White River Basin, Indiana, 1995.

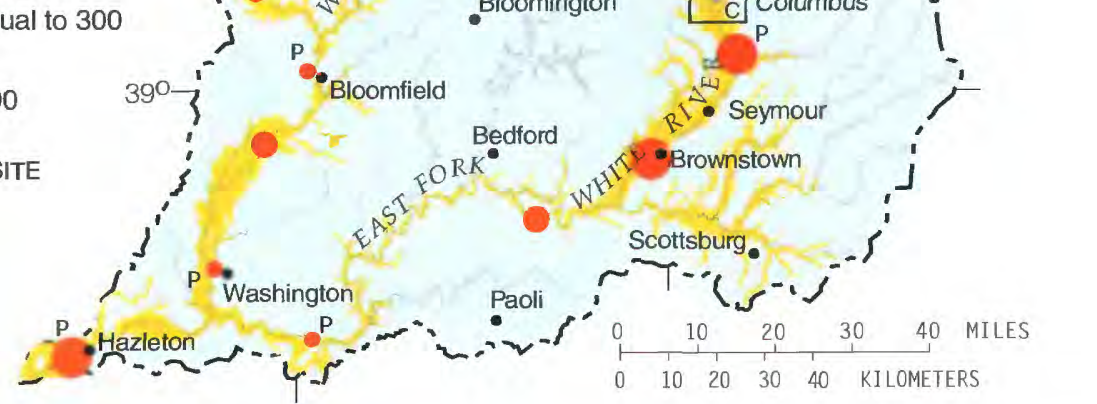




\section{STUDY APPROACH}

Two monitoring-well networks were installed in the upper part of the fluvial aquifers of the White River Basin (fig. 1). A network of 23 shallow monitoring wells was installed in an agricultural setting and a network of 25 shallow monitoring wells was installed in the urban settings of Indianapolis, Anderson, and Columbus (insets A, B, and C in fig. 1). These 48 wells ranged in depth from 12.5 to 40 feet deep and are referred to as "shallow wells" in this paper. Nine additional "deep wells" (40 to 62 feet deep) were drilled adjacent to selected shallow wells to allow comparison of radon concentrations by depth. Each deep well was completed in the same aquifer as the adjacent shallow well but was screened 18 to 45 feet deeper. The depth of the deep wells was dictated by the depth to the bottom of the uppermost fluvial aquifer or by the limit of the drill rig (50 to 70 feet). All wells were constructed of 2 -inch polyvinyl chloride (PVC) casing fitted with 2.5- to 5 -foot screens. Well construction and installation procedures are described in Lapham and others (1995).

Procedures described in Koterba and others (1995) were used to collect water samples in summer 1995 from all 57 wells. Radon concentrations were determined by liquid scintillation at the U.S. Geological Survey National Water Quality Laboratory in Denver, Colo. Precision estimates reported by the laboratory for the 57 samples ranged from $+/-12$ to $+/-37 \mathrm{pCi} / \mathrm{L}$ (picocuries per liter) of radon.

\section{FINDINGS}

Radon concentrations in water from the shallow monitoring wells ranged from 140 to $1,600 \mathrm{pCi} / \mathrm{L}$; the median concentration was $420 \mathrm{pCi} / \mathrm{L}$. Radon concentrations in ground water in Indiana are low as compared to those in many parts of the eastern and western United States. For example, concentrations in ground water throughout the Appalachian Mountains generally range from 1,000 to $10,000 \mathrm{pCi} / \mathrm{L}$ (Michel and Jordana, 1987). A survey by the American Water Works Company (Dixon and Lee, 1987), which included 28 public-supply wells in Indiana, reported radon concentrations that were lower than those reported in this study. Radon concentrations in the 28 public-supply wells ranged from less than 100 to $624 \mathrm{pCi} / \mathrm{L}$ and averaged $324 \mathrm{pCi} / \mathrm{L}$.

Because radon is a human carcinogen, the U.S. Environmental Protection Agency (EPA) has proposed a Maximum Contaminant Level (MCL) of $300 \mathrm{pCi} / \mathrm{L}$ for radon in drinking water. (A proposed MCL may be used for guidance but has not been through the EPA public notice and comment procedures.) Although the monitoring wells used in this study are not used for drinking water, the fluvial aquifers in the White River Basin are used widely as a source of water. Radon concentrations from approximately 70 percent of the shallow wells sampled in this study exceeded $300 \mathrm{pCi} / \mathrm{L}$. Water samples from the deep wells, however, may be more representative of publicly supplied ground water in the basin. Radon concentrations in only 33 percent of the deep wells exceeded $300 \mathrm{pCi} / \mathrm{L}$.

No areal trends in radon concentrations are evident in the shallow fluvial aquifers of the White River Basin (fig. 1). This absence of trends may indicate that radon-bearing sands and gravels are well distributed within the upper part of the fluvial aquifers in the basin. Dixon and Lee (1987) reported higher radon concentrations in ground water in east-central Indiana than in west-central Indiana; however, their samples were collected from a variety of aquifers.

Analyses of samples from the nine paired wells indicate that radon concentrations decrease with depth in the fluvial aquifers (fig. 2); the median concentration of radon in water from the deep wells was $210 \mathrm{pCi} / \mathrm{L}$. It is unclear why radon concentrations decrease with depth. A possible explanation is that greater concentrations of uranium-bearing minerals are present in the shallow (younger) parts of the fluvial aquifers than in the deep (older) parts of the fluvial aquifers because of different geologic sources for the shallow and deep deposits. Other factors that may contribute to differences in radon concentrations with depth include differences in the particle size and porosity of the aquifer deposits and the presence of mineral coatings on grains (Thomas Kraemer, U.S. Geological Survey, oral commun., 1996).

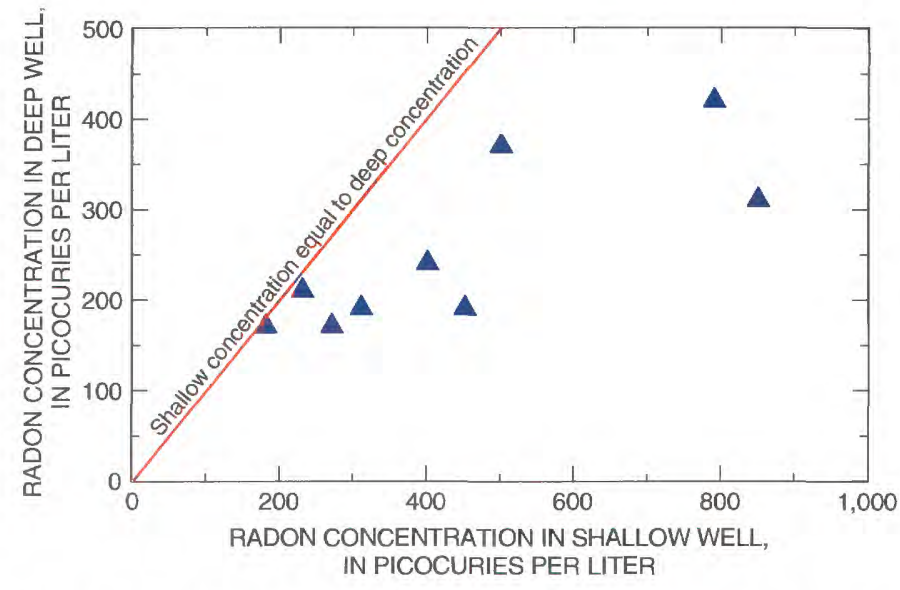

Figure 2. Radon concentrations in samples from paired shallow and deep monitoring wells in the fluvial aquifers of the White River Basin, Indiana.

\section{REFERENCES CITED}

Dixon, K.L., and Lee, R.G., 1987, Radon survey of the American Water Works system, in Graves, Barbara (ed.), Radon, radium, and other radioactivity in ground water: Chelsea, Mich., Lewis Publishers, p. 311-346.

Fenelon, J.M., Bobay, K.E., and others, 1994, Hydrogeologic atlas of aquifers in Indiana: U.S. Geological Survey Water Resources Investigations Report 92-4142, 197 p.

Hirsch, R.M., Alley, W.M., and Wilber, W.G., 1988, Concepts for a national water-quality assessment program: U.S. Geological Survey Circular 1021, 42 p.

Koterba, M.T., Wilde, F.D., and Lapham, W.W., 1995, Ground-water data-collection protocols and procedures for the National WaterQuality Assessment Program - Collection and documentation of water-quality samples and related data: U.S. Geological Survey Open-File Report 95-399, 113 p.

Lapham, W.W., Wilde, F.D., and Koterba, M.T., 1995, Ground-water data-collection protocols and procedures for the National WaterQuality Assessment Program-Selection, installation, and documentation of wells, and collection of related data: U.S. Geological Survey Open-File Report 95-398, 69 p.

Michel, J., and Jordana, M.J., 1987, Nationwide distribution of Ra-228, $\mathrm{Ra}-226, \mathrm{Rn}-222$, and $\mathrm{U}$ in groundwater, in Graves, Barbara (ed.), Radon, radium, and other radioactivity in ground water: Chelsea, Mich., Lewis Publishers, p. 227-240.

U.S. Environmental Protection Agency, 1995, Drinking water regulations and health advisories: Washington, D.C., U.S. Environmental Protection Agency, Office of Water, 11 p.

U.S. Geological Survey Fact Sheet 124-96 Prepared by

Joseph M. Fenelon and Rhett C. Moore

For more information, contact:

Project Chief

White River Basin Study

U.S. Geological Survey

5957 Lakeside Blvd.

Indianapolis, Indiana 46278-1996

317-290-3333 